\title{
STUDY OF PATTERN OF VISUAL IMPAIRMENT IN PATIENTS SEEKING VISUAL DISABILITY CERTIFICATE
}

Shubhratha Sathish Hegde ${ }^{1}$

${ }^{1}$ Senior Resident, Department of Ophthalmology, Mysore Medical College and Research Institute.

PURPOSE ABSTRACT

To determine the severity and various causes of visual impairment in patients seeking visual disability certificate.

\section{METHODS}

Cross-sectional study of patients seeking visual disability certificate from November 2014 to April 2015 was done. Severity of visual impairment was calculated as per the guidelines of Ministry of Social Justice and Empowerment 1999. Cause was ascertained after detailed examination which included slit-lamp examination, direct ophthalmoscopy, indirect ophthalmoscopy, slit-lamp biomicroscopy with 78D lens, Humphrey visual field analysis wherever necessary.

\section{RESULTS}

Of the 267 patients, category 0-7 (2.62\%), category 1-37 (13.85\%), category 2-42 (15.73\%), category 3-157(58.80\%), one eyed24 (8.98\%). Male preponderance was seen (56.55\%). The causes were congenital malformations-78 (29.21\%), retinitis pigmentosa71 (26.59\%), refractive errors with amblyopia-52 (19.47\%), corneal opacity related to trauma and infectious keratitis $22(8.23 \%)$, glaucoma-14 (5.24\%), phthisis bulbi-9 (3.37\%), ARMD-3 (1.12\%), miscellaneous-9 (3.37\%). The causes were preventable in $41.19 \%$.

\section{CONCLUSION}

Most of the patients who sought disability certificate were totally blind. The leading causes for visual impairment were congenital malformations, retinitis pigmentosa and refractive errors with amblyopia. 41.19\% patients suffered from visual impairment caused by potentially preventable conditions. The burden of visual impairment can be reduced by taking necessary preventive measures with the leading causes being identified.

\section{KEYWORDS}

Visual Disability Certificate, Congenital Malformations.

HOW TO CITE THIS ARTICLE: Hegde SS. Study of pattern of visual impairment in patients seeking visual disability certificate. J. Evolution Med. Dent. Sci. 2016;5(36):2111-2113, DOI: 10.14260/jemds/2016/495.

\section{INTRODUCTION}

Blindness is a devastating physical condition with deep emotional and economic implications. The consequences affect not only the individual but also the family and the community.1,2 According to WHO 180 million people worldwide are visually disabled of whom nearly 45 million are blind. Of the estimated 45 million, India alone has 8.9 million blind people, which comes to about one fifth of the total in the world. The problem of blindness in India is not only of its gigantic size, but also of its causes, which are largely preventable. About $80 \%$ of blindness is potentially preventable. 1,3

The current study is undertaken to study, ascertain the cause of visual impairment and to identify the leading causes of preventable blindness among the patients seeking visual disability certificate. The prevention of blindness is an international priority and its planning requires contemporary data regarding its incidence and causes, based on which priorities for its prevention, treatment and management can be identified.

Financial or Other, Competing Interest: None.

Submission 08-03-2016, Peer Review 14-04-2016,

Acceptance 20-04-2016, Published 04-05-2016.

Corresponding Author:

Dr. Shubhratha Sathish Hegde,

Senior Resident,

Department of Ophthalmology,

Mysore Medical College and Research Institute,

Mysore.

E-mail:drshubhratha@gmail.com

DOI: 10.14260/jemds/2016/495
Meagre available data and increasing magnitude of blindness warrants this study.

\section{MATERIALS AND METHODS}

Cross-sectional study of patients seeking visual disability certificate from November 2014 to April 2015 was done. Data was collected using pre-structured pretested proforma. Sociodemographic profile including the educational status and occupation was obtained. Cause of blindness was ascertained after detailed examination which included slit-lamp examination, direct ophthalmoscopy, indirect ophthalmoscopy, slit-lamp biomicroscopy with 78D lens, applanation tonometry, Humphrey visual field analysis wherever necessary and feasible. Severity of visual impairment was calculated as per the guidelines of Ministry of Social Justice and Empowerment 1999.4

\begin{tabular}{|c|c|c|c|}
\hline Category & $\begin{array}{c}\text { Best Corrected } \\
\text { Visual Acuity in } \\
\text { the Better Eye }\end{array}$ & $\begin{array}{c}\text { Best Corrected } \\
\text { Visual Acuity in } \\
\text { the Worst Eye }\end{array}$ & $\begin{array}{c}\text { Percentage of } \\
\text { Visual } \\
\text { Disability }\end{array}$ \\
\hline 0 & $6 / 9-6 / 18$ & $6 / 24-6 / 36$ & $20 \%$ \\
\hline I & $6 / 18-6 / 36$ & $6 / 60$ to Nil & $40 \%$ \\
\hline II & $\begin{array}{c}6 / 40-4 / 60 \text { or } \\
\text { field of vision } \\
10^{\circ}-20^{\circ}\end{array}$ & $3 / 60$ to nil & $75 \%$ \\
\hline III & $\begin{array}{c}3 / 60 \text { to } 1 / 60 \text { or } \\
\text { field of vision } 10^{\circ}\end{array}$ & F.C. at $1 \mathrm{ft.}$ to Nil & $100 \%$ \\
\hline IV & $\begin{array}{c}\text { F. C. at } 1 \mathrm{ft} \text { to Nil } \\
\text { or field of vision } \\
10^{\circ}\end{array}$ & $\begin{array}{c}\text { F.C. at } 1 \mathrm{ft} \text { to Nil } \\
100 \%\end{array}$ \\
\hline $\begin{array}{c}\text { One eyed } \\
\text { persons }\end{array}$ & $6 / 6$ & $\begin{array}{c}\text { F.C. at } 1 \mathrm{ft} \text {. to Nil } \\
\text { or field of vision } \\
10^{\circ}\end{array}$ & $30 \%$ \\
\hline
\end{tabular}


Statistical analysis was done by using Epi-info software. The variables of interest were age, gender, occupation, percentage of disability and the cause of visual disability.

\section{RESULTS}

Of the 267 patients, $56.55 \%$ (151) were males and $43.45 \%$ (116) were females with M:F ratio being 1.3:1.

Visual disability of $100 \%$ was noted in $58.80 \%$ (157). $15.73 \%$ (42) had $75 \%$ visual disability, $13.85 \%$ (37) had $45 \%$ visual disability, $2.62 \%$ (7) had $20 \%$ visual disability. $8.98 \%$ (24) of the patients were one eyed with visual disability of 30\%. (Table-1)

Most of the patients, $38.57 \%$ (103) were in the age group of $<20$ years, followed by $21-40$ years group with $35.58 \%$ ( 95 ). $14.6 \%$ (39) were in age group of $41-65$ years and $11.2 \%$ (30) were above 65 years. (Table-2)

Majority 85.76\% (229) were unemployed, $10.48 \%$ (28) were students, $3.74 \%$ (10) were self-employed.

The causes were congenital malformations-78 (29.21\%), retinitis pigmentosa-71(26.59\%), refractive errors with amblyopia-52(19.47\%), corneal opacity related to trauma and infectious keratitis 22(8.23\%), glaucoma-14 (5.24\%), phthisis bulbi-9 (3.37\%), ARMD-3 (1.12\%), miscellaneous-9 (3.37\%). The causes were preventable in $41.19 \%$. (Table-3)

\begin{tabular}{|c|c|}
\hline $\begin{array}{c}\text { Amount of Visual } \\
\text { Disability }\end{array}$ & $\begin{array}{c}\text { Number of Visually } \\
\text { Disabled }\end{array}$ \\
\hline $20 \%$ & $7(2.62 \%)$ \\
\hline $40 \%$ & $37(13.85 \%)$ \\
\hline $75 \%$ & $42(15.73 \%)$ \\
\hline $100 \%$ & $157(58.8 \%)$ \\
\hline $30 \%$ ( One eyed) & $24(8.98 \%)$ \\
\hline Table 1: Number of Visually Disabled in Each Category \\
\hline
\end{tabular}

\begin{tabular}{|c|c|}
\hline Age (years) & Number of Visually Disabled \\
\hline$<20$ & $103(38.57 \%)$ \\
\hline $21-40$ & $95(35.58 \%)$ \\
\hline $41-65$ & $39(14.6 \%)$ \\
\hline$>65$ & $30(11.2 \%)$ \\
\hline \multicolumn{2}{|c|}{ Table 2: Age Distribution } \\
\hline
\end{tabular}

\begin{tabular}{|c|c|}
\hline $\begin{array}{c}\text { Causative } \\
\text { Factor }\end{array}$ & $\begin{array}{c}\text { Number of Visually } \\
\text { Disabled }\end{array}$ \\
\hline Congenital malformations & $78(29.21 \%)$ \\
\hline Retinitis pigmentosa & $71(26.59 \%)$ \\
\hline Refractive errors with amblyopia & $52(19.47 \%)$ \\
\hline $\begin{array}{c}\text { Corneal opacity related to trauma } \\
\text { \& infectious keratitis }\end{array}$ & $22(8.23 \%)$ \\
\hline Glaucoma & $14(5.24 \%)$ \\
\hline Phthisis bulbi & $9(3.37 \%)$ \\
\hline ARMD & $3(1.12 \%)$ \\
\hline Miscellaneous & $9(3.37 \%)$ \\
\hline Table 3: Causes of Visual Disability \\
\hline
\end{tabular}

\section{DISCUSSION}

The impact of visual loss on the personal, economic, and social life of an individual is profound, and when the prevalence of blindness in communities is high like in India, the consequences become a significant public issue.2,5 Data collected in this study may be useful to the governmental agencies to plan the strategies for rehabilitation and prevention of blindness. Several observations of our study conform to those of previous studies at different geographical settings.
In our study, male preponderance was seen. This could be attributed to the fact that certification system is institution based and females may not be able to access it due to social obstacles. This finding is in accordance with the findings of the study conducted by Kareemsab et al., ${ }^{6}$ Joshi et al. ${ }^{7}$ and Gosh et al. ${ }^{8}$ However, in the 58th round of the NSSO survey ${ }^{9}$, nearly $54 \%$ of the total visual impaired individuals were females and the remaining $46 \%$ were males, depicting a female gender bias.

In our study, young patients were in a significant majority compared to the elderly. Most of the patients were in the age group of $<20$ years and in $21-40$ years age group. This suggests that certification is sought for educational, employment and conveyance benefits which are more likely to serve the purpose of young individual than the elderly. Study by Gosh et al. ${ }^{8}$ also showed similar results.

Unemployment in our study was consistent with the findings of the NSSO survey. ${ }^{9}$ which observed that $80 \%$ of the blind individuals in the rural areas are without any source of income. Similar findings were noted in study by Gosh et al. ${ }^{8}$

In this study, patients with $100 \%$ disability formed the majority group. A similar finding was noted by Kareemsab et al., ${ }^{6}$ Gosh et al. ${ }^{8}$ and Bunce et al. ${ }^{10}$

Congenital malformations was the leading cause for visual disability in our study followed by retinitis pigmentosa and refractive errors. This is similar to the findings of the study by Kareemsab et al., ${ }^{6}$ Ghosh et al. ${ }^{9}$

The causes were preventable in $41.19 \%$ of the patients. With better health education, eye care and compulsory periodic school eye screening their incidence can be reduced. Limitation of the study is that the exact prevalence of visual disability cannot be obtained as the registration is voluntary. Another limitation was that the rates could not be calculated as we had no specific population denominator as this was a hospital based survey, and we depended only on the number of cases. Since it is not a community based survey, it may not give the true reflection of the distribution of various causes of visual disability.

\section{CONCLUSION}

Given the current predictions that the number of blind people worldwide will roughly double by the year 2020, it is clear that there is no room for complacency. This study certainly gives an idea about the most prevalent causes for visual disability and hence helps to plan preventive measures.

Congenital ocular malformations dominated as the main cause for obtaining visual handicap certificate, followed by retinitis pigmentosa and refractive errors with amblyopia. It is estimated that $41.19 \%$ suffer from visual impairment caused by potentially preventable conditions. The burden of visual impairment can be reduced by taking necessary preventive measures with the leading causes being identified. Similar studies can be conducted in other parts of the country to identify the prevalent causes for visual impairment and blindness. Such studies will also help in finding the geographical differences in the causes of visual handicap.

\section{REFERENCES}

1. The causes and prevention of blindness. In Ramanjit Sihota, Radhika Tandon, ed. Parson's diseases of the eye. New Delhi, Elsevier, 2015;22nd edn:562-76. 
2. Sheila West, Alfred Sommer. Prevention of blindness and priorities for the future. Bull of the World Health Organization 2001;79(3):244-8.

3. Global trends in the magnitude of blindness and visual impairment, Aug 6, 2015. available from http://www.who.int/blindness/causes/trends/en/

4. Guidelines for the evaluation of various disabilities and procedures for certification. The Gazette of India extraordinary Part 1, Section 1; No 154.

5. Thulasiraj RD, Nirmalan PK, Ramakrishnan R, et al. Blindness and vision impairment in a rural south Indian population: the Aravind comprehensive eye survey. Ophthalmology 2003;110(8):1491-8.

6. Kareemsab D, Rachaiah NM, Balasubramanya. Prevalence of leading causes of certification for blindness and partial sight. Journal of Clinical and Diagnostic Research 2011;5(8):1624-6.
7. Rajesh S Joshi. Causes of visual handicap amongst patients attending outpatient department of a medical college for visual handicap certification in central India. Journal of Clinical Ophthalmology and Research 2013;1(1):17-9.

8. Sambuddha Ghosh, Subhalakshmi Mukhopadhyay, Krishnendu Sarkar, et al. Evaluation of registered visually disabled individuals in a district of West Bengal, India. Indian Journal of Community Medicine 2008;33(3):168-71.

9. National Sample Survey Organization, Ministry of Statistics and Programme Implementation, Government of India. Round Number 37th in 1981, 47th in 1991 and $58^{\text {th }}$ in 2002.

10. Bunce C, Wormald R. Causes of blind certifications in England and Wales: April 1999-March 2000. Eye 2008;22(7):905-11. 